\title{
Where sexuality and spirituality meet: An assessment of Christian teaching on sexuality and marriage in relation to the reality of 21st century moral norms
}

\begin{abstract}
Author:
Marilize E. Tukker ${ }^{1}$

Affiliation:

${ }^{1}$ Faculty of Theology,

University of Pretoria,

South Africa

Note:

Marilize E. Tukker is participating as research fellow of Prof. Dr Dirk J. Human, Deputy Dean of the Faculty of Theology of the University of Pretoria, Pretoria, South Africa. This article represents a reworked version of a thesis submitted in fulfilment of the degree MA (Biblical and Religious Studies) at the University of Pretoria, under the supervision of Prof. Dr P.A. Geyser.
\end{abstract}

Correspondence to: Marilize Tukker

Email:

metukker@gmail.com

Postal address:

Private Bag X20, Hatfield

0028, Pretoria, South Africa

Dates:

Received: 16 Oct. 2012

Accepted: 29 June 2013

Published: 26 Sept. 2013

How to cite this article: Tukker, M.E., 2013, 'Where sexuality and spirituality meet: An assessment of Christian teaching on sexuality and marriage in relation to the reality of 21st century moral norms', HTS Teologiese Studies/ Theological Studies 69(1), Art. \#1343, 8 pages. http:// dx.doi.org/10.4102/hts. v69i1.1343

Read online:
Christians and the church tend to shy away from talking about sex, premarital sex and sex outside of marriage. God and sex are rarely mentioned in the same sentence, and yet people still have a deep need for spirituality, to experience God in their lives and to seek guidance on sexual matters. It becomes a dilemma when the question is posed: where do sexuality and spirituality meet? One way to answer this question is to attempt to find a link between spirituality and sexuality. In this way, spirituality could gain relevance, and expressing one's sexuality could find a moral foundation. People are both spiritual and sexual creatures - with the need to express their spirituality and sexuality in a moral, but unashamedly natural way. This article attempts to find alternative solutions for our complex society - on the subject of marriage and sexuality. The intention is not to dismiss the institution of marriage, but rather to renegotiate the terms and structure of marriage in the 21st century.

\section{Introduction}

A former preacher at die Gereformeerde Kerk van Suid Afrika (GKSA) - J.J. Viljoen - wrote in the newspaper Beeld (2009:22) about his experiences as a preacher. He tells the story of a young couple who wanted to join the church - but who were rejected because they were living together with their children and were not married. The church committee stipulated that the couple should live separately for a period of time, after which they should get married and baptise their two children. This had to take place before they would be accepted as members of the church, and only at that stage would they be able to take Holy Communion. The fact that the couple had been committed to each other for 10 years, had raised their children as believers, and had worked hard to preserve their family unit - was never considered. Needless to say, the family did not join the church. Ironically, during his years of service in the church, Viljoen had to counsel numerous couples whose 'papers' were in order, but whose marriages had fallen apart a long time ago. Their place in the church and their right to take Holy Communion were, however, guaranteed (Viljoen 2009:22)

The traditional monogamous marriage is being questioned - not only because of different modern practices in sexual relationships, but also because of the inconsistencies and sometimes contradictions apparent in the Bible itself. It is impossible to give only one viewpoint on the topic based on what the 'Bible says'. Modern society questions the assertion that traditional marriage is the only moral and lawful option where a permanent love relationship between two people can exist. In fact, the complexity of relationships in modern society is not being accommodated in the traditional marriage (Viviers 2006:90).

The church is currently confronted with a divergence of opinion about sexual relationships and marriage. The reality of our society raises the question of whether the traditional understanding of marriage is still relevant - in terms of helping believers make meaningful and responsible choices.

The topic of Christian sexual ethics raises various questions. When it comes to ethics, people often cite certain biblical texts literally, in order to justify their specific viewpoint. If we look closely, however, the Bible still provides guidelines for healthy relationships. Although it has been argued that the Bible does not give us all the answers for our ethical questions, there are still clues to be found with regard to how people can be both sexual creatures and Christians at the same time (Dreyer 2008:483-491).

This article discusses a variety of issues relating to the Christian church, marriage and sex - with the aim of suggesting a moral foundation for sexuality, relationships and marriage. Particular

Copyright: (c) 2013. The Authors. Licensee: AOSIS OpenJournals. This work is licensed under the Creative Commons Attribution License. 
reference is made to the Old Testament book, Song of Songs, as the nature and context of the love relationship presented here offers important clues to answering the dilemmas facing modern Christian couples, when facing issues relating to marriage, sex and morality in the context of the 21st century.

\section{Why do so many Christians associate sex with sin?}

The negative view on sexual intimacy started in the early church, where it was taught that sex is meant for procreation and not for enjoyment. In the two decades after Christ, the church got so caught up with the depravity of women and sexual desires, that sex and sin almost became synonyms. By the 7th century, Pope Gregorius declared that a couple was impure if they gained any pleasure from sex. The sin of pleasure had become twice as substantial as that associated with the sex deed itself (Friesen 1990:175).

Sex was always treated in the church as something that should not be talked about. Vardy (1997) summarises the moral norms on sexuality that have played a major role in the church for several centuries. These are: sex before marriage is wrong; homosexual behaviour is wicked; adultery is against the law of God; masturbation is a grave sin; the main purpose of sex is procreation; sex is only acceptable within the confines of a marriage of one man and one woman; a woman has a duty to provide sexual access to a man if she is married to him; sex is to be treated with suspicion when it is a temptation; and, celibacy is a higher ideal than married life (Vardy 1997:xi). Although most of these uncompromising views have been overcome in the last few decades, the church is still faced with new challenges in the present milieu - which require reflection on existing theologies.

\section{Associating sex with shame}

Shame can be described as the feeling that creates the need to cover up or hide. Healthy shame helps us to make good judgement and to know when we contradict our own beliefs. Unhealthy shame would be to compare and force our beliefs on others. Churches, communities and cultures use shame to protect the traditions of the culture and to keep religious laws sacred. Shame is directed at those who violate the rules.

Shame is passed down from one generation to another. In this regard, so many children still grow up today hearing that sex is wrong and shameful. Auten (1990) points out how parents' attitudes are influencing their children - especially when it comes to sex and sexuality:

Most of the attitudes and values that cause sexual problems among young couples, can be traced back to attitudes, behaviour and values that are either consciously or unconsciously absorbed from parents. (p. 86)

Furthermore, according to McClintock (2001):

When we don't talk about sexuality, we reinforce media images of it as something separate from spirituality. The gap between sexuality and spirituality (spirit-body dualism) is a place where shame grows. (p. 12)
This could lead to many unanswered questions about sexuality and looking for answers in the wrong places. Rather than to ignore it - would it not be better to educate young people about sex, advice, warn them about potential dangers, and teach them values that are biblically grounded? I concur with McClintock (2001), when she says:

We can teach our children about sexuality and biblical moral standard by emphasizing love, commitment, and consequence. We don't need to shame them in order to teach them. We can teach them to value good communications in sex by the way we ourselves communicate with them about sex. (p. 56-57)

McClintock (2001) suggests that it is our silence on the subject of sexual shame that has contributed to the decline in church membership. It has in fact been noted that people drop out of church for an average of 8 years between high school and young adulthood - around the same time when they reach the so-called 'sexual peak' years. It is during this dropout phase that sexuality without spiritual values can be learned. This has various negative implications:

Without spiritual grounding for sexual relationships, young people are increasingly likely to engage in dangerous sexual practices. Sexuality and spirituality need to be taught in the same curriculum. One without the other leaves us unfulfilled. (McClintock 2001:12)

\section{Song of Songs}

\section{The Song of Songs and sexuality}

'Your lips cover me with kisses; your love is better than wine', is the opening line of Song of Songs (1:2). It sounds exciting - but could this centuries-old song shed some light on relationships in the 21st century? There is in fact plenty to learn from this book of the Old Testament. Song of Songs is considered to be the greatest love poem ever written $(\mathrm{Du}$ Toit 2007:121).

The rabbis questioned the place of the Song of Songs in the Canon, because of the book's erotic language and the difficulty associated with its interpretation. The positive resolution of that debate is reflected in the famous declaration by Rabbi Akiva, that:

The whole world is not worth the day on which the Song of Songs was given to Israel; all the Writings are holy, but the Song of Songs is the holies of holies. (Van Leeuwen 2003: 1518-1519)

Song of Songs is typically interpreted as the relationship between God and Israel or between Christ and the church. According to these interpretations, Song of Songs is not about sexuality or sexual love, but rather about a sexual religion, or 'holy, godly love' (Scheffler 2008:1265). Song of Songs is sexually extremely explicit - by openly referring to the naked male and female bodies, especially their sexual organs and to sexual activities. There are no elements in the book to suggest that these acts should be interpreted as God's relationship with his people. In fact, there is no reference to God, at all (Scheffler 2008:1265).

Perhaps the clearest biblical teaching on sexuality is found in Song of Songs. The book talks about a man and a woman 
who are desperately in love with each other: 'How beautiful you are, my love; how your eyes shine with love! How handsome you are, my dearest; how you delight me' (Song of Songs 1:15-16). They yearn to be together, but not simply for the sake of sexual gratification. They want to be together because they are in love, and the sex they enjoy with one another is an expression of that love. Their mutual attraction is not primarily hormonally driven.

The way the Bible talks about the love between a man and a woman is somewhat surprising. On the subject of sexuality and marriage, people often expect the Bible to have a set of instructions, with rules and regulations. In Song of Songs, however, it is surprising to note that sexuality and marriage are praised. It is, after all, not a narrative, nor a lecture it is a song. In fact, it is named in the superlative: Song of Songs. We are invited to celebrate love - to join in, and sing and dance and be joyful about love, and to be amazed that people are capable of loving each other. This poetry holds a timelessness that speaks straight to the heart. And where love is being celebrated, it brings us closer to the mystery of being human - the secret of life itself (Du Toit 2007:122).

Senses play an important role in Song of Songs. The couple are listening, seeing, tasting, smelling and touching - and through it all there is a passion that leaves one speechless. Christians often feel that the Bible is against physical desire and sexual feelings. They tend to see sexual desires as sinful and that passion can lead to seduction. This is not the case. Indeed, Song of Songs portrays passion as something beautiful and powerful (Du Toit 2007:123).

The main theme of Song of Songs is that the couple belong to one another. Only in the exclusiveness of their relationship and in the security of the mutual - I belong to you and you belong to me - is this love that they share, possible. This exclusiveness is also expressed in other ways - for example, that his beloved is unique, and one of a kind that only happens once in a lifetime. And for her beloved, she is irreplaceable (Du Toit 2007:125).

A love relationship encompasses the entire human existence - your heart, thoughts, body and ultimately your life. Emotions are often contradictory: joy and yearning, pride and shyness, self-confidence and uncertainty. All this and more are part of the Song of Songs' love experience. These different features of love are seen in the themes that occur throughout the songs: including longing, desire, admiring, wonder, spring cheer, enjoying erotic playfulness and the uniqueness of the beloved (Du Toit 2007:126).

If Song of Songs were to be read as a textbook on how to have sex, Solomon's intent would be misunderstood. The book is a guide on how to build a loving, intimate relationship. The ultimate purpose of sex is to provide ultimate intimacy between a husband and wife. There is no greater expression of vulnerable intimacy between human beings, and this is a large part of what makes marriage so unique.
To create a safe environment for erotica and lovemaking love, trust, care and commitment should be present. If this is the case, it would be understood that eros not only implies sexuality, but also sensuality; that the atmosphere in which sex takes place is just as important as the sex itself. Song of Songs talks about a love that should be celebrated, but it also holds a calling. We celebrate love - because when we love, we live. That is why we live with enthusiasm and passion, but also with gratitude and amazement. This calling never ends; the duty of love is not ever accomplished or completed. This is why the end of the Song of Songs is left open and unfinished (Du Toit 2007:136).

\section{The Song of Songs and marriage}

The age-old book Song of Songs has much to teach modern society about sexuality. Although it is not mentioned once that the couple is married - why do we still assume that they are? It could be that the writer is cautious (and perhaps withholding the truth) about upsetting conservative readers, who are not ready to hear about sex before marriage (Viviers 2006:92). In spite of the fact that there is no indication that the couple are married, they enjoy each other's bodies to the full. This is unexpected, as one would have expected the Bible to be very strict - especially when discussing sexuality and marriage.

According to Fox (1985:309-313) the two characters imagine themselves in fictional parts - in the same way they imagine themselves to be 'bride' and 'groom'. Therefore we can assume they did foresee a marriage somewhere in the future, although the only thing that matters at that moment is the passionate love they feel for each other. The author does not undermine or reject marriage, but rather places it in perspective. True and faithful love is what is important. The milieu where it happens is secondary - and this includes a sexual relationship (Viviers 2006:101).

For generations, people were discouraged from talking openly about sex, as though it were something to be ashamed of. Yet there is this book in the Bible that talks beautifully about sexuality, and explicitly talks about physical desire, passion and pleasure (Du Toit 2007:121-136). The false notion that sex is wrong and sinful, should be set right, in order to restore sex to being a beautiful gift from God. What message does it send out to adolescents if adults constantly avoid the subject? The questions raised by puberty are difficult enough to deal with, and acting as if sexuality is wrong and sinful does not make it easier. Nevertheless, this sensitive issue should be dealt with circumspectly.

Although we do not know whether the couple in Song of Songs are married, the main theme of the book - that they belong to one another - sends out a strong message about the values that a relationship should have. The love they share could only exist between two people. The fact that they have saved their passion for each other probably indicates that they have saved themselves for each other, and that they have not shared this kind of love with anyone else. The sex 
that they enjoy is only possible in a relationship where love, trust, care and commitment are present (Viviers 2006:101). The relationship between the two characters is exclusive and committed; no third party is welcome in their intimate relationship. They are not bothered by status, wealth and power - things that usually destroy relationships. Their relationship is playful and interesting. They respect each other as equals, and both are willing to make sacrifices.

It is ironic that Song of Songs portrays the virtues of an ideal marriage, and yet it is never mentioned that the couple are married (Viviers 2006:102). Faithful love is what it is all about - not marriage or the name that is given to it. According to Fox (1985:315): 'The Song does assume a sexual ethic, but the sexual virtue cherished is not chastity. It is fidelity: unquestioned devotion to one's lover...'

\section{Contextual interpretation}

According to Thatcher (2002:76) '[ $t]$ he term "marital norm" conveys the conviction that, within the Christian faith, marriage is the norm (but not necessarily the rule) for full sexual experience.' Norms and values are, however, subject to change over time. The contemporary norm system is very different from what was considered right and wrong in biblical times (Müller 2007:379). In this regard, the Reformed Church in the Netherlands (In Liefde Trouw zijn) calls for a distinction between contextual norms - which are formulated in each time period - and the basic values that are found in the Bible. It is thus necessary to re-evaluate what the Bible says about marriage and sex in today's context.

A contextual interpretation of the Bible does not imply a move away from the clear evangelical norms of Jesus Christ. An evangelical instead of a legalistic approach does not mean that there are no norms or values when it comes to sexuality. Rather, with an evangelical approach, the emphasis is on morals rather than on rules. For instance: the rule would be 'no sex before marriage', whilst the moral would be that a sexual relationship is meant for a steady, long-lasting relationship where two people love each other and celebrate that love by being intimate. In this relationship the partners accept responsibility for each other within a love covenant (Müller 2007:378).

A value- or norm-based approach could never work with rigid rules, because the emphasis is on personal freedom and responsibility. The legalistic approach leads to rule upon rule - which leads to conviction. This latter method, followed by the Pharisees and teachers of law, attempts to control and condemn people. With the evangelical approach, couples instead accept responsibility for each other (Müller 2007:378).

Müller (2007:379) identifies four fundamental principles necessary in a relationship - in order to overrule the line theory (where sex before marriage is wrong, but once married it is a gift from God). The most important values are mutual reciprocity, freedom and security between two people, and a relationship that is long lasting. If these values are present in a relationship, the question about what side of the line sex occurs is irrelevant. What is more important is the nature of the sexual relationship. Values like these are based on the great commandment, to love God and to love your neighbour. With these in mind, casual, superficial and experimental sex could never be justified. If one is fanatical about 'the law', one could throw the first stone. But who is without sin, and what makes sex a bigger sin in many minds than any other sin (Müller 2007:379)?

All four fundamental values are interlinked: a long-lasting sexual relationship with elements of aggression or violence is not safe, and the people involved do not feel secure and free. Therefore such a relationship would be destructive. If the line theory were to be strictly applied, one would be tempted to argue that the couple in such a relationship should stay together because ' $[n]$ o human being must separate, then, what God has joined together' (Mt 19:6). If this is the case, we allow abuse to rule over love - which defies the overarching message of the Bible. Jesus shows us that our devotion to the law should not compromise neighbourly love. For example, the Pharisees believed that you were not to prepare food or heal a human being on the Sabbath because the law forbids you to work on that day. Jesus' response to this was '[i]t is kindness that I want, not animal sacrifices' (Mt 12:7).

All considered, however, one cannot argue that mutual reciprocity, freedom and security are enough to justify a sexual relationship. A long-term commitment should be part of a sexual relationship - if not, it can be abused. It should be remembered that the people involved in a relationship are always more important than the institution. The protection of the institution of marriage can be said to promote a healthy society - which is in the best interest of society (Müller 2007:380).

\section{Ethics}

The topic of Christian sexual ethics raises various questions. How can Christian ethical principles be applied in different and changing social contexts? Where do these principles come from? When it comes to ethics people often use certain biblical texts literally to validate their specific viewpoint. When it comes to homosexuality or sex before marriage, it is expected that the Bible should have direct normative statements against such issues. However, the Bible does not say much about these topics at all (Haspel 2007:263).

When we consult the New Testament on sexual ethics, we encounter two obstacles. In the first place, an ethic that has equal authority for everyone does not exist. Secondly, the New Testament is not a textbook about moral issues. The New Testament in fact does not offer explicit suggestions about ethics relating to gender roles, marriage or sexuality (Le Roux 2010:1).

The only real Christian ethic is love for God and your neighbour. Therefore, we must apply this ethic to marriage and sexuality. Agape should be a non-negotiable condition for 
any sexual relationship. Not all marriages, however, pass this test. The idea that all marital sex is acceptable and premarital sex is wrong can no longer be simply accepted. The values and the manner in which the relationship defines itself and the integrity of the relationship, is far more important. These values include love, respect, unselfishness, trust, exclusivity, continuity and being accommodating and responsible (Le Roux 2010:2). Ash (2003) astutely observes that:

Contrary to contemporary culture we shall find that the answer is not in terms of 'what sex can do for me', nor even of what sex can do for a sexual partner or for a couple; rather, sex is to be used in the service of God. Only when sex is understood in this context of wider service will sexual ethics make transcendent sense. (p. 16)

One of the main problems that Christian sexual ethics has to deal with today - is the question of whether the church should acknowledge and bless unmarried long-term relationships. Biblical traditions already illustrate that this institution is changing and subject to development. For many people marriage is no longer the beginning of an intimate relationship. Rather, it is seen as part of the process - after a couple have lived together for several years and perhaps wants to start a family. A couple who live together out of wedlock should not be criticised, but rather should be questioned on whether they live together responsibly (Haspel 2007:268).

\section{Legal marriage or religious marriage?}

It is interesting to note that Christian traditions (and others) are generally more concerned about the when of sex, than the quality of sex. Parents, teachers and the church are more concerned about sex outside wedlock, than they are about loving, meaningful sex in marriages. Scheffler (2008:1261) states that sex before marriage is not the obvious cause of divorce, but rather the absence of good sex within marriages. Instead of rejecting, condemning or forbidding sex, preachers, psychiatrists and sexual counsellors should rather encourage people to experience their sexuality religiously, and to live accordingly. $\mathrm{Nel}$ (1998) states that:

sex needs to be placed within the context of both personal and public relationships. In a value system that places the sexual within the relational, the focus will be on the relationship, instead of on the sexual aspect. (p. 400)

Couples who are already living together should be encouraged to do so in love and to interpret their sexuality in a religious way, instead of being encouraged to develop guilt that pushes them away from the church. In the same way, married couples should not be left to their own fate. Their sexual relationship should be supported and encouraged. This would prevent divorce. Fellow Christians and counsellors should focus on promoting meaningful sex in marriages (where they probably could make a difference) - rather than condemning sex before marriage (which they cannot do anything about) (Scheffler 2008:1261).

The increasing divorce rate, along with the remarriage of divorcees, raises the question of whether the traditional view of marriage as a lifelong commitment is still relevant under all circumstances. Premarital sex is already an acceptable norm for young adults, which forces one to look into the church's view of the meaning and purpose of sexual intimacy. The increasing number of cohabiting couples in the church, living together in a trial marriage, or even as an alternative to marriage, requires new theological reflection on different types of marriages (Van Niekerk 2007:327).

One of the main problems of contemporary sexual ethics is whether the church should acknowledge non-marital, longterm relationships, and under which circumstances. The debate about cohabitation has two possible solutions. One possibility is that the church can decide to treat cohabitation situations that have all the characteristics of a good marriage - as real marriages. This would be very difficult to control through the synod. However, the church could provide guidelines to ministers to apply in their ministries, at their own discretion, and according to each individual case. Another possibility would be to conceptually separate a religious marriage from a constitutional marriage. If this were the case, senior citizens, for example, could have a church wedding and not be married legally - without losing the pension of one of the partners. The question in fact is how members of the church can live responsibly before God with the decision they have made (Retief 2002:21).

More liberal churches have no problem with marrying couples who want a religious wedding, but do not want to get married legally - whatever their reasons. The Dutch Reformed Church does not, however, approve of doing this. Rev. Kosie Delport - actuary of the Western Cape Dutch Reformed synod - states that the Dutch Reformed Church will only marry a couple on condition that a lawful marriage is incorporated. He states that a religious wedding alone gives a sense of false security. Although the couple may think of themselves as being married in God's eyes - nothing legally binds them. Women are especially vulnerable in these instances. Rev. Delport admits that the Bible does not provide specific information on the form marriage should take, but rather regards the acknowledgement of society as being important (Retief 2002:21).

For the church to consider accepting non-marital relationships, such relationships should have the same characteristics and values as a marriage. The values that the Bible teaches for God-worthy relationships should be applicable to all relationships. Socially and ethically, a partnership that resembles a marriage deserves respect, protection and recognition - as long it is ethically justified in a way that is analogous to matrimony and is exercised in a responsible way. It has to be assumed that the couple plan to live together permanently - with personal devotion and faithfulness (Körtner 2008:219).

\section{The church's stance}

The church's teaching about sex seems to be contradictory. On the one hand it regards sex as sinful, whilst on the other 
hand it preaches that it should be saved for the person you love (Berry 2005:15). People are encouraged to remain chaste until they marry, and then share this beautiful experience with the spouse long-term. For centuries this was the attitude of the church towards sex - something that is wrong before marriage, but thereafter it is a beautiful gift from God. Unmarried couples '... are caught somewhere between the culture's sexual "do everything" and the Church's "do virtually nothing'" (Cahill 2001:170). This restricted understanding of sex is summarised by Grey and Selling (2001:189 cited in Muller \& Pienaar 2003:145), who stated that young persons are still being told that sex is dangerous, cheap and a serious source of moral guilt, unless one is married - which somehow makes the very same acts legitimate, although not really all that pleasant.

The question seems to be how the church should think about instances where relationships display all the characteristics of a healthy marriage, except for the fact that the couple is not legally married. Within the church there is disagreement on the matter. One group considers cohabitation in longterm, stable relationships as being immoral and sinful. They believe that the couple should confess their sin in order to receive God's grace and then marry so that they no longer live in sin. The other group believes that words like sin, guilt, repentance and forgiveness should be replaced with a different language of faith - which should include the healing of broken people, and a ministry that would lead people to spiritually good relationships. In many cases people who live together in fact have healthier relationships than married people; often they are believers who are active in the community and the church.

Should the church look past the legitimacy of the relationship and acknowledge it as something that is in essence already a marriage? The church's viewpoint on human sexuality has changed continually throughout its history. As it became a dominant influence in society, the church's attitude towards sexuality has always had a strong cultural influence. Therefore, a decision by the church about the treatment of cohabiting couples is bound to have a profound influence on society. However, it will also be a watershed decision for the continued existence of the church itself.

\section{Law or love?}

John 8:3-11 talks about a woman who was caught redhanded committing adultery. The teachers of the law and the Pharisees brought this woman to Jesus, explaining what she had done and what Moses commanded on the matter. This woman meant nothing to them; the most important thing was the law and that they rigidly adhere to it - whatever the cost. The Pharisees tried to trap Jesus into judging this woman and condemning her to death by stoning (Jn 8:3-11). Jesus responded by writing in the sand. The sand of Palestine is probably the worst medium possible to write on, because the words would only be briefly visible. Within a few minutes the wind would obliterate them. He purposely wrote in the sand to symbolise that the law - which was so important to them - was also transient. He knelt down next to the woman and asked who would throw the first stone, symbolising solidarity with her and sending a message that the woman was more important to him than the law (Müller 2007:374).

In fundamentalist theology a simple, single line exists - a line that authorises the legal marriage - involving the state and a church ceremony. On the one side of the line sexual intercourse is sinful; on the other side it is good, healthy and necessary. This line separates the sinners from the 'good people' (Müller 2007:374). This theory can no longer apply to modern society. Young Christians have adopted a better value system: responsible sex is part of a steady love relationship. This type of relationship is a more responsible biblical approach than the legalistic approach that encourages juridical marriage as the only norm for sexual intercourse. Norms for sexual intercourse should be sought at a deeper level than just the line of the juridical marriage (Müller 2007:374).

\section{Marriage as a process}

The big question about marriage is: when does it begin? The way people think about marriage today differs immensely from the way they thought about it in biblical times. Today the wedding ceremony is regarded as the start of a marriage. However, marriage cannot be compared to a race with a starting point and an end point - it should rather be viewed as a process.

The wedding ceremony is the public announcement of a couple's love and devotion towards each other-which started a long time ago. That is why cohabiting is in fact neither bad nor wrong, because it could be part of the marriage process. If, however, cohabiting is merely a convenient arrangement without any future plans, or when it becomes a substitute for marriage - it is not part of the marriage process, and could lead to many problems (Dreyer \& Van Aarde 2007:678).

Thatcher (1999:111) also emphasises that marriage is a process, rather than a clearly defined rite of passage. He suggests that engagement should formally become part of the process of marriage. In this way, a couple could promise faithfulness to each other and enter the first phase of marriage - with the prospect of a wedding ceremony thus making it official. In the case of cohabitation, the state should be responsible for the regulation of jurisdiction to protect the rights of both parties. The church, however, has the responsibility to guide the couple pastorally - to understand that living together is a phase leading towards a possible permanent marriage before God. Sex would become part of the later, more intimate phase, and every couple should decide for themselves when they are ready to enter this phase. Mutual commitment is essential for the couple's intimacy, both sexually and spiritually, to grow stronger (Dreyer \& Van Aarde 2007:678).

\section{Conclusion}

According to Belleville (2010:19) 'one danger of living in a non-Christian world is becoming conformed to the world's 
standards rather than being transformed by God's standards.' If churches become too accommodating, they would look no different at society, and yet a shift away from the universally right or wrong of sexual moral behaviour is needed. There could never be a one-sentence rule that could sum up sexual and marital ethics. If there were, the sentence would most definitely come down to love - as love is the universal 'rule' for any relationship, especially a sexual relationship.

'An "anything goes" perception does not benefit a social constructionist narrative understanding of life and identity' (Müller \& Pienaar 2003:141). Social constructionism acknowledges that individuals and society need boundaries, and that without boundaries individuals become dysfunctional and chaotic personalities (Nel 1998:395). However, boundaries need to be open to renegotiation according to changing contexts over time. There could never be the adage 'open the Book and recite the appropriate universally applicable answer to sexuality' (Gerkin 1991:12).

Marriage as it is understood today has come a long way since biblical times. Each generation has moulded the marriage concept to make sense of it within its own cultural context. Is it fair to say that the Bible does not provide adequate guidelines on the subjects of marriage and sex, and therefore each generation revised the few rules to suit them? The fact that morality is changing is undeniable. We will have to make a responsible distinction between cultural customs and religious values, for our culture will be ever-changing and customs that were once acceptable are no longer acceptable today.

Living together or premarital sex should not be seen as wrong or sinful - provided it is part of a marriage process. Cohabiting and sex before marriage could only be acceptable when a couple have mutual respect and love for each other, and a future expectation from each other. Living together and sex could become part of the process that eventually leads to a public declaration before people and God - of the couple's love and commitment towards each other in the form of a marriage covenant. We should not be blinded by the so-called integrity of the marriage. Rather, we should be examining the integrity of the relationship, of which marriage is a symbol.

We should stop using sex to shame people. Rather, we should educate people, especially adolescents, about the value and power of one's sexuality. Young people need help to understand their own sexuality, advice on how to deal with their own sexuality as well as that of others, and should be warned about the potential dangers of sex. The young, old, married or unmarried need guidance on sexuallyrelated questions and, most importantly, the values that are biblically grounded.

On the one hand the Bible confirms the more conservative message that God's ideal for sex is to be enjoyed within a marriage. On the other hand it is no coincidence that a text such as Song of Songs is to be found in the Bible. Perhaps the purpose is to teach us what is more important: love, respect, faithfulness and commitment - or an institution called marriage. It must still be noted that the preferred context for a sexual relationship is marriage, although it may not be the only context. Sex is still a skill best learned in the context of marriage.

We should attempt to keep what is good about marriage as we know it, and then find reasonable solutions for our complex society to accommodate the wider spectrum of beliefs held by Christians. What then could be a basic guideline that connects sexuality and spirituality? The answer is comparing a relationship to the standards that Song of Songs represents. If free sex implies careless, irresponsible, immoral sex - it cannot be associated with the kind of sexual relationship that Song of Songs portrays. Sex in the Song of Songs may be before marriage - but it is everything but immoral. Moral sex is characterised by love, faithfulness, commitment, and equal respect. Where these virtues are not present - even if it is in a legal marriage - sex would be immoral.

We must lead the way in terms of educating couples about their sexual responsibilities, in modelling healthy marriages - but also in accepting relationships that might be different from the so called 'norm'. It is our responsibility to find common ground for all believers to share in the grace of God and with the freedom that comes from accepting oneself and others just as we are: sexually diverse, but spiritually strong, individuals.

\section{Acknowledgements Competing interests}

The author declares that she has no financial or personal relationship(s) which may have inappropriately influenced her in writing this article.

\section{References}

Ash, C., 2003, Marriage: Sex in the service of God, Inter-Varsity Press, Nottingham.

Auten, R.D., 1990, The role of the Church in helping early adolescents deal with issues of sex and sexuality, University Microfilms International, Ann Arbor, MI. PMid:2223103

Belleville, L.L., 2010, Sex, lies, and the truth, Wipf \& Stock Publishers, Eugene, OR. PMCid:PMC2966439

Berry, C.R., 2005, The unauthorized guide to sex and the church, Thomas Nelson, Nashville, TN.

Brand, C., Draper, C. \& England, A., 2003, Holman illustrated Bible dictionary, Holman Bible Publishers, Nashville, TN.

Cahill, L.S., 2001, 'Sexuality: Personal, communal, responsible', in J.A. Selling (ed.), Embracing sexuality: Authority and experience in the Catholic Church, pp. 165172, Ashgate Publishing Company, Burlington.

Clendenen, E.R. \& Kelly, B.R., 2003, s.v. 'Marriage', in C.W. Draper, C. Brand \& A England (eds.), Holman illustrated Bible dictionary, Holman Bible Publishers, Nashville, TN, pp. 1082-1084.

Dreyer, Y., 2008, "De-centre-ing" sexual difference in public and ecclesial discourses on marriage', HTS Teologiese Studies/Theological Studies 64(2), 715-738. http:// dx.doi.org/10.4102/hts.v64i2.41

Dreyer, A.E. \& van Aarde A.G., 2007, "n Krities-hermeneutiese perspektief op die huwelik in 'n postmoderne era', HTS Teologiese Studies/Theological Studies 63(2), 653-681. http://dx.doi.org/10.4102/hts.v63i2.225

Du Toit, D.R.S., 2007, 'Liefkosings: Lekkerder as wyn - liefdesgenieting in die boek Hooglied', in C. Vos \& H. Human (reds.), Liefde is die grootste, bl. 121-137, Protea Boekhuis, Pretoria. 
Fox, M.V., 1985, The Song of Songs and ancient Egyptian love songs, University of Wisconsin Press, Madison, Wl.

Friesen, L.J., 1990, 'Marriage: A biblical model in historical perspective', PhD thesis, Department of Theology, Talbot School of Theology, Biola University.

Gerkin, C.V., 1991, Prophetic pastoral practice: A Christian vision of life together Abington, Nashville, TN.

Grey, M. \& Selling, J.A., 2001, 'Marriage and sexuality in the Catholic Church', in J.A. Selling (ed.), Embracing sexuality: Authority and experience in the Catholic Church, pp. 179-183, Ashgate Publishing Company, Burlington.

Haspel, M.P., 2007, 'Christelike seksuele etiek in 'n tyd van MIV/Vigs', in C. Vos \& D. Human (reds.), Liefde is die grootste, bl. 262-281, Protea Boekhuis, Pretoria.

Körtner, U.H.J., 2008, 'Sexuality and partnership: Aspects of theological ethics in the field of marriage, unmarried and homosexual couples', HTS Teologiese Studies/ Theological Studies 64(1), 209-225. http://dx.doi.org/10.4102/hts.v64i1.18

Le Roux, E., 2010, "n Johannese perspektief op die huwelik, geslagsrolle en seksualiteit in 'n postmoderne konteks', Verbum et Ecclesia 31(1), 1-8. http:// dx.doi.org/10.4102/ve.v31i1.347

McClintock, K.A., 2001, Sexual shame: An urgent call to healing, Fortress Press, Minneapolis, MN.

Müller, J.C., 2007, 'Seks en die huwelik: Evangelie in plaas van Wet', in C. Vos \& D. Human (reds.), Liefde is die grootste, bl. 372-381, Protea Boekhuis, Pretoria.

Müller, J.C. \& Pienaar, H.E., 2003, 'A social-constructionist, narrative understanding of the church's morality on sex', Verbum et Ecclesia 24(1), 137-155.
Nel, F.B.O., 1998, 'An ecological approach to the quest for new horizons in the Christian view of sexuality', in M.A. Hayes, W. Porter \& D. Tombs (eds.), Religion and sexuality: Studies in theology and sexuality, vol. 2, pp. 380-404, Sheffield Academic Press, London. (Roehampton Institute London Papers, 4).

Retief, H., 2002, 'Tot die dood ons skei nie meer die norm: Die huweliksboot dobber onrustig rond', Rapport, 09 Junie, bl. 21.

Scheffler, E., 2008, 'Eros as godsdiens (of die religieuse viering van seks)', HTS Teologiese Studies/Theological Studies 64(3), 1255-1277. http://dx.dol. org/10.4102/hts.v64i3.80

Thatcher, A., 1999, Marriage after modernity, New York University Press, New York, NY.

Thatcher, A., 2002, Living together and Christian ethics, Cambridge University Press, Cambridge. http://dx.doi.org/10.1017/CBO9780511613432, PMCid:PMC2376145

Van Leeuwen, R.C., 2003, s.v. 'Song of Songs, Songs of Solomon', in C.W. Draper, C. Brand \& A. England (eds.), Holman Illustrated Bible dictionary, Holman Bible Publishers, Nashville, TN, pp. 1518-1519

Van Niekerk, A., 2007, 'Spiritualiteit en erotiek - nie opponent nie maar vennote', in C. Vos \& D. Human (reds.), Liefde is die grootste, bl. 315-328, Protea Boekhuis, Pretoria. http://dx.doi.org/10.1017/CBO9780511613432, PMCid:PMC2376145

Vardy, P., 1997, The puzzle of sex, HarperCollins, London. PMCid:PMC1722245

Viljoen, J.J., 2009, 'Kerk is dikwels net struikelblok', Die Beeld, 15 Desember, bl. 22.

Viviers, H., 2006, 'Huwelik of nie - wat van hooglied?', Verbum et Ecclesia 27(1), 90106. http://dx.doi.org/10.4102/ve.v27i1.150 